\title{
Role of Diffusion-Weighted MRI in Colorectal Cancer
}

\author{
NEHAL K. MOHAMED, M.Sc.; EMAN A. AHMAD, M.D.; MOHAMED Z. MOHAMED, M.D. and \\ ABO EL-HASSAN H. MOHAMED, M.D.
}

The Department of Diagnostic Radiology, Faculty of Medicine, Assiut University

\begin{abstract}
Background: To reveal the adding value of diffusionweighted Magnetic Resonance Imaging (MRI) in the detection and differential diagnosis of the colorectal cancer, comparing the results of Apparent Diffusion Coefficient (ADC) value with histopathological studies.

Aim of Study: The aim of the study was to determine the effectiveness of MRI in the diagnosis of colorectal cancers and to reveal the adding value of DWI in the detection and differential diagnosis of the colorectal cancer, comparing the results of ADC value with histopathological studies.

Material and Methods: Fifteen patients with suspected colorectal cancers clinically, endoscopically or by CT and US images were included in this study. All cases have been evaluated with $1.5 \mathrm{MR}$ scanner. In addition to the conventional sequences (T2-axial, sagittal and coronal weighted images (WI), axial T2 STIR, T1 WI and a Diffusion-Weighted Images (DWI) with 4 different b-values $\left(0,400,600\right.$ and $1000 \mathrm{~s} / \mathrm{mm}^{2}$ and ADC maps were obtained then the results have been compared to histopathological diagnosis.
\end{abstract}

Results: All cases of malignant colorectal cancer showed high signal (restricted diffusion) on DWI. Receiver Operating Curve (ROC) analysis of ADC values yielded an Area Under Curve $\underline{-}_{3}$ (AUC) of 0.912 , setting a threshold ADC value of $<1.1$ X $10 \mathrm{~mm} / \mathrm{sec}$ yielded a sensitivity of $82.8 \%$ and specificity of $100 \%$ in detecting the malignant colorectal masses.

Conclusion: DWI with high b-values and ADC value is a feasible method and has the potential to be effective in detection of colorectal cancer.

Key Words: Colonic cancer-MRI-DWI-Apparent diffusion coefficient $(A D C)$.

\section{Introduction}

COLORECTAL Cancer (CRC) is the third most common cancer in the United States in both men and women and it is very common in Egypt. About $65 \%$ of CRC are distal to the splenic flexure and potentially detectable by the sigmoidoscopy. Con-

Correspondence to: Dr. Nehal K. Mohamed, The Department of Diagnostic Radiology, Faculty of Medicine, Assiut University trariwise, $35 \%$ of CRC are proximal to the sigmoid and not detectable by the sigmoidoscopy. About $20 \%$ to $25 \%$ are presented with Dukes D colon cancer with identifiable distant metastases [1]. MRI is considered one of the most accurate and sensitive diagnostic tools for the detection of CRC and its loco-regional spread.

Diffusion-Weighted MRI (DWMRI) is becoming increasingly important in the assessment of malignant tumors $[2,3]$. It is generally accepted that DW-MRI enables noninvasive characterization of biologic tissues on the basis of their water diffusion properties [4].

By performing DWI using different b-values, quantitative analysis is possible with the calculation of the ADC, measured in $\mathrm{mm}^{2} / \mathrm{sec}$. Areas of restricted diffusion show low ADC values. ADC values are inversely correlated with tumor cellularity and reductions in ADC correlate with response to cytotoxic therapy.

Moreover, DWI has been shown to be feasible as an early marker of treatment response because cell death and vascular alterations typically occur before size changes. Increases in ADC values with treatment reflect decreases in cellularity and thus provide indirect assessment of chemotherapy induced cell death [5].

\section{Patients and Methods}

\section{Study population:}

During a period of 16 months between May 2014 and September 2015, a prospective observational study was applied on a total of 15 patients with suspected colorectal cancers either clinically, endoscopically or by CT and US images were found in our institution and were included in this study. The selected sample was obtained from the 
Department of Surgery, Unit of Endoscopy and the MRI Unit at Assiut University Hospitals.

\section{Inclusion criteria:}

Patients in different ages with suspected colorectal cancers clinically, endoscopically or by CT and US images were included in this study.

\section{Exclusion criteria:}

1- Prior biopsy.

2- Any general contraindication of MRI as presence of any paramagnetic substance as pacemakers or those with claustrophobia; and

3- Severely ill patients or inability of patients to cooperate when performed MR imaging.

\section{Each patient was subjected to the following:}

A- Radiological assessment: MRI abdomen and pelvis:

The standard MRI protocol performed for all patients was as follows: MRI examination was performed using a 1.5 Tesla MR Imager scanner (Achieva; Philips Medical Systems) using abdominal phased array Torso coil in the supine position. The following sequences were obtained:

1- Coronal turbo spin-echo T2-weighted image: Repetition time (TR) 526ms, Echo time (TE) $80 \mathrm{~ms}$, slice thickness $5 \mathrm{~mm}$, Field of View (FOV) $425 \mathrm{~mm}$, matrix 304 X 264, Flip Angle (FA) (900) and Acquisition time 1:06min.

2- Axial turbo spin-echo T2-HR weighted image: TR $1670 \mathrm{~ms}$, TE $100 \mathrm{~ms}$, slice thickness $5 \mathrm{~mm}$, FOV 375mm, matrix $400 \times 224$, FA (900) and Acquisition time 4:03min.

3- Sagittal turbo spin-echo T2-weighted image: TR 526ms, TE $80 \mathrm{~ms}$, slice thickness 5mm, FOV $425 \mathrm{~mm}$, matrix 304 X 264, FA (900) and Acquisition time 1:06min.

4- Axial T1 FFE-weighted image: TR260ms, TE $46 \mathrm{~ms}$, slice thickness $5 \mathrm{~mm}$, FOV $375 \mathrm{~mm}$, Matrix 240 X 118, FA (800) and Acquisition time 15sec.

5- Axial T2-STIR weighted sequence: TR $768 \mathrm{~ms}$, TE $80 \mathrm{~ms}$, slice thickness $7 \mathrm{~mm}$, FOV $273 \mathrm{~mm}$, Matrix 304 X 209, FA (900) and Acquisition time 2:36min.

6- DWI, an axial single shot echo-planar pulse sequence with 4 different b-values $(0,400,600$ and $1000 \mathrm{~s} / \mathrm{mm}^{2}$ ) was acquired with a single breath-hold without requiring the injection of paramagnetic contrast. ADC map performed and ADC value measured .TR $1348 \mathrm{~ms}$, TE $65 \mathrm{~ms}$, slice thickness $7 \mathrm{~mm}$, FOV $375 \mathrm{~mm}$, matrix 124 $\mathrm{X}$ 100, FA (900) and Acquisition time 2:36min.
B- Biopsy: The results have been compared to histopathological diagnosis:

Data analysis and image interpretation:

$M R$ imaging analysis:

MR images were analyzed for the following:

1 - Site, size and signal intensity of the mass.

2- Infiltration of the perilesional fat planes.

3- Infiltration to the surrounding structures.

4- Presence of enlarged regional lymph nodes.

5- Presence or absence of distant metastasis and their sites.

6- Associated other MRI findings as ascites.

\section{Interpretation of DWI:}

Qualitative analysis:

Evaluation of the signal intensity: The mass may show one of the following appearances:

- Low signal intensity on diffusion images with low signal in the corresponding ADC maps (facilitated).

- High signal intensity on diffusion images with lowering of the signal in the corresponding ADC maps (restricted).

\section{Quantitative analysis:}

Regarding the quantitative analysis of DWI, we generated the ADC map data on the work station. ADC values from the mass were measured using the largest possible Region of Interest (ROI) for each patient (about $37 \mathrm{~cm}^{2}$ ). The ADC measurements were repeated three times with different ROI's placed in a different part of the mass. The average of these measurements was calculated.

\section{Statistical analysis:}

Data were checked, entered and analyzed using computer programs Microsoft Excel 2010 and statistical program for social science, Version 15 (SPSS Inc., Chicago, Illinois, USA) as follows: Description of quantitative variables as range, mean, Standard Deviation (SD), median, frequencies (number of cases) and percentages when appropriate; description of qualitative variables as number and percentage, Sensitivity, specificity, accuracy, predictive values of positivity and negativity of MRI study and DWI were recorded. $p$ values $<0.05$ was considered statistically significant.

\section{Results}

Fifteen patients ( 6 males and 9 females patients with ages ranging from 25 to 66 years and average age of 47.6 years) were included in our study. 
In our study, the most common risk factor for CRC among the patients is family history of CRC by percent of $(20 \%)$.

According to (Table 1), the most common location of colorectal mass among our patients is (the recto-sigmoid region) with the liver presenting the most common site of CRC metastasis.

According to (Table 2), the most common histopathological subtype of colorectal mass among our patients is (the moderately differentiated adenocarcinoma) with percent of $(53.3 \%)$.

Distribution of patients as regards histopathological diagnosis was as follows 12 patients were positively diagnosed $(80 \%)$ and 3 patients was negatively diagnosed (20\%).

\section{Diffusion weighted image and $A D V$ values:}

According to exhibit of MRI-DWI of colorectal masses in our study, we found significant change in signal intensity of colorectal masses-either benign or malignant-on DWI which is statistically significant as shown in (Table 3 ).

The mean ADC values of the benign and malignant colorectal mass in ADC maps were compared by independent $t$-test and showing statistically significant in ADC as illustrated in (Table 4) and Fig. (1).

Receiver Operating Characteristic (ROC) analysis was used to calculate the Area Under the Curve (AUC) for determining a threshold ADC value that best separated the benign and malignant masses while maximizing average specificity and sensitivity.

The ADC value could significantly differentiate the malignant colorectal masses with cut off value $<1.1$ at a sensitivity of $82.8 \%$ and specificity of $100 \%$ (Table 5) and Fig. (2).

Table (1): Show location of the colorectal mass, distant metastasis and site of these metastases.

\begin{tabular}{lll}
\hline & No. & $\%$ \\
\hline Mass location: & & \\
Colon & 2 & 13.3 \\
Rectum & 1 & 6.7 \\
Ano-rectum & 3 & 20.0 \\
Sigmoid & 3 & 20.0 \\
Recto-sigmoid & 6 & 40.0 \\
Metastatic: & & \\
Yes & 4 & 26.7 \\
No & 11 & 73.3 \\
Site of metastasis: & & \\
Liver & 3 & 20.0 \\
Lung & 0 & 0.0 \\
Peritoneal deposit & 1 & 6.7 \\
Vertebral body & 1 & 6.7 \\
\hline
\end{tabular}

Table (2): Show the histopathological results of colorectal masses in our study.

\begin{tabular}{lll}
\hline Histopathology & No. & $\%$ \\
\hline Chronic inflammation & 3 & 20.0 \\
Mod. diff. adenocarcinoma & 8 & 53.3 \\
Poorly diff. adenocarcinoma & 3 & 20.0 \\
Mucinous & 1 & 6.7 \\
\hline
\end{tabular}

Table (3): Comparison between MRI-DWI in benign and malignant colorectal masses.

\begin{tabular}{cccccc}
\hline & \multicolumn{2}{l}{ Benign $(\mathrm{n}=3)$} & \multicolumn{2}{l}{ Malignant $(\mathrm{n}=12)$} & \multirow{2}{*}{$p$-value } \\
\cline { 2 - 5 } & No & $\%$ & No & $\%$ & \\
\hline $\begin{array}{c}\text { NWI } b \text { 150: } \\
\text { Facilitated }\end{array}$ & 2 & 66.7 & 0 & 0 & $0.002 * *$ \\
Restricted & 1 & 33.3 & 12 & 100 & \\
DWI $b$ 500: & & & & & \\
Facilitated & 2 & 66.7 & 0 & 0 & $0.002 * *$ \\
Restricted & 1 & 33.3 & 12 & 100 & \\
PWI $b$ 1000: & & & & & $0.002 * *$ \\
Facilitated & 2 & 66.7 & 0 & 0 & \\
Restricted & 1 & 33.3 & 12 & 100 & \\
\hline
\end{tabular}

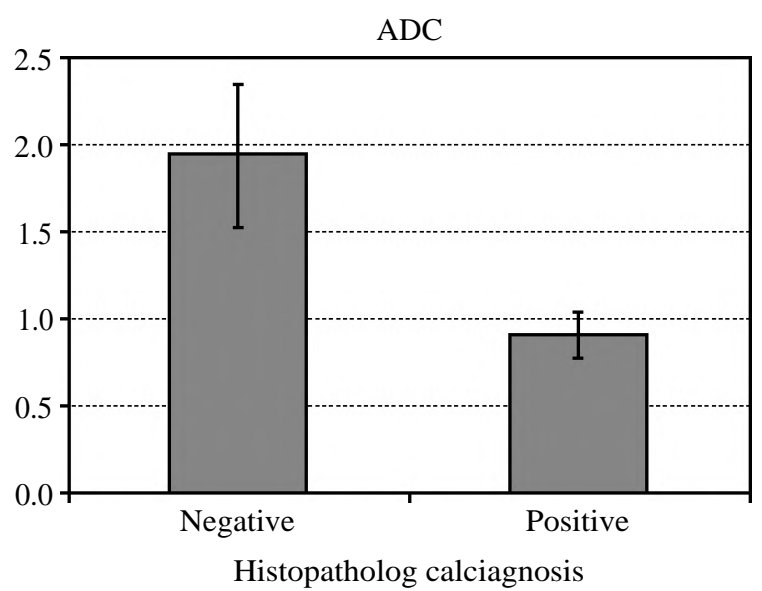

Fig. (1): Graph show relation between histopatho logical diagnosis and ADC.

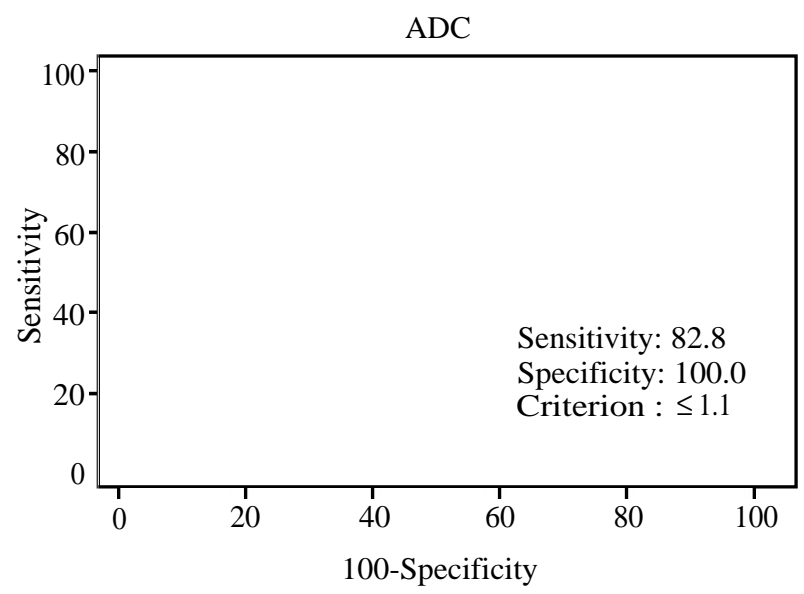

Fig. (2): Diagram show ROC curve of ADC value for cut off to histopathological diagnosis. 


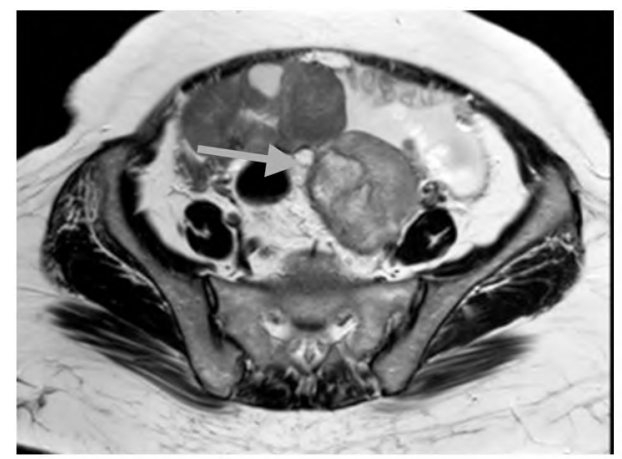

(A) Axial T2WI

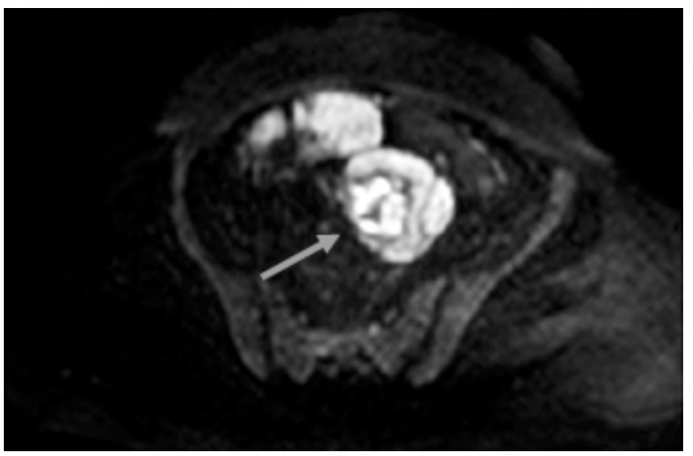

(C) Axial DWI at b 1000

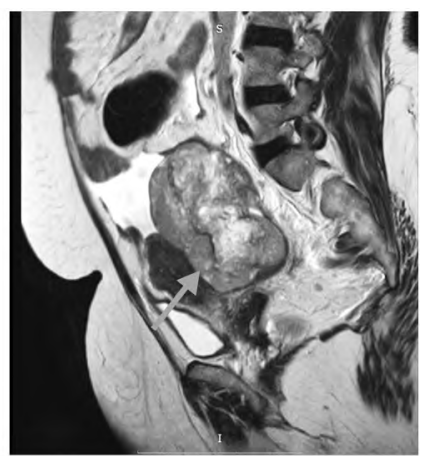

(B) Sagittal T2WI

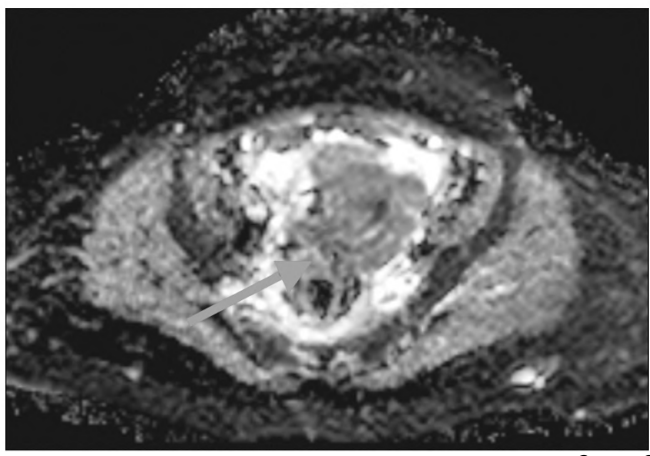

(D) ADC map and ADC value $\left(0.783 \times 10^{-3} \mathrm{~mm}^{2} / \mathrm{sec}\right)$

Fig. (3): Female patient, 55 years old, presented by bleeding per rectum. (A,B) Images show heterogenous intensity soft tissue mass involving the rectosigmoid region in term of diffuse circumferential annular thickening with multiple peritoneal deposits and mild aşcites 2 (C,D) Images show restricted diffusion at the above-mentioned rectosigmoid mass with ADC value $=0.783 \times 10^{-3} \mathrm{~mm} / \mathrm{sec}$. The histopathological diagnosis was Adenocarcinoma Grade II.

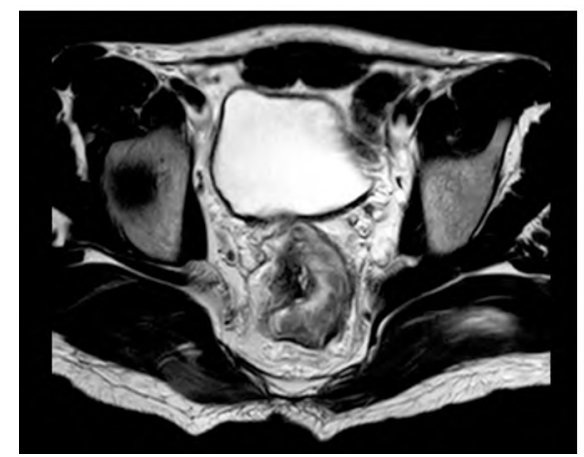

(A) Axial T2WI

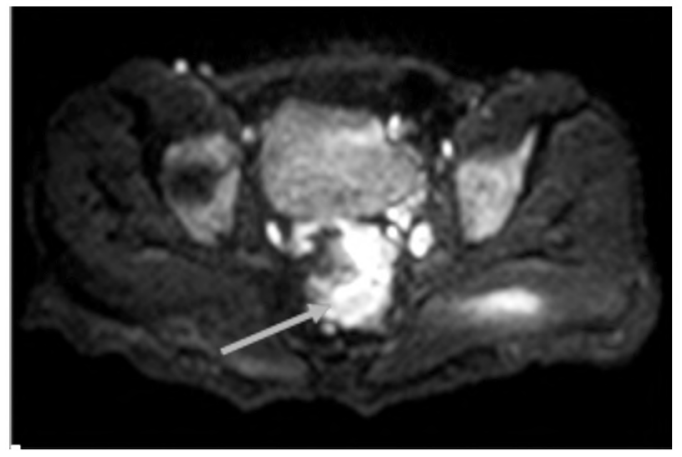

(C) Axial DWI at b 1000

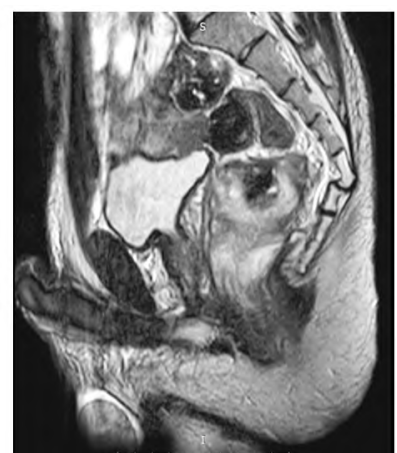

(B) Sagittal T2WI

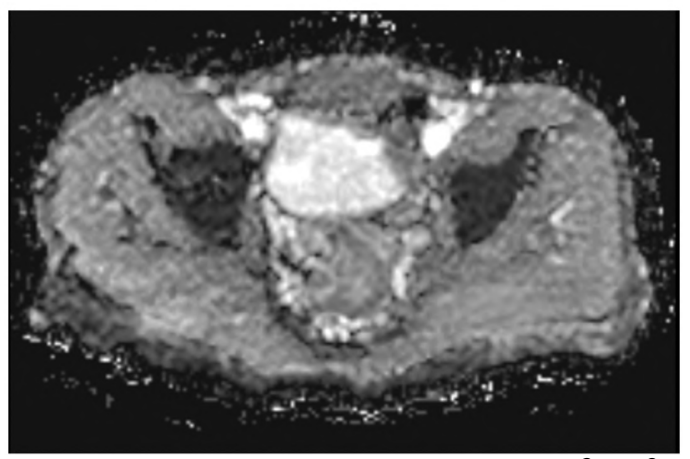

(D) ADC map and ADC value $\left(0.946 \times 10^{-3} \mathrm{~mm}^{2} / \mathrm{sec}\right)$

Fig. (4): Male patient, 30 years old, presented by intestinal obstruction and constipation. (A,B) Images show anorectal mass with infiltration of perirectal fascia and deep pelvic, iliac, obturator and inguinal lymph nodes. (C,D) Images show restricted diffusion at the above-mentioned anorectal mass with $\mathrm{ADC}$ value $=0.946 \times 10 \mathrm{~mm} / \mathrm{sec}$. The histopathological diagnosis was moderately differentiated mucinous carcinoma. 


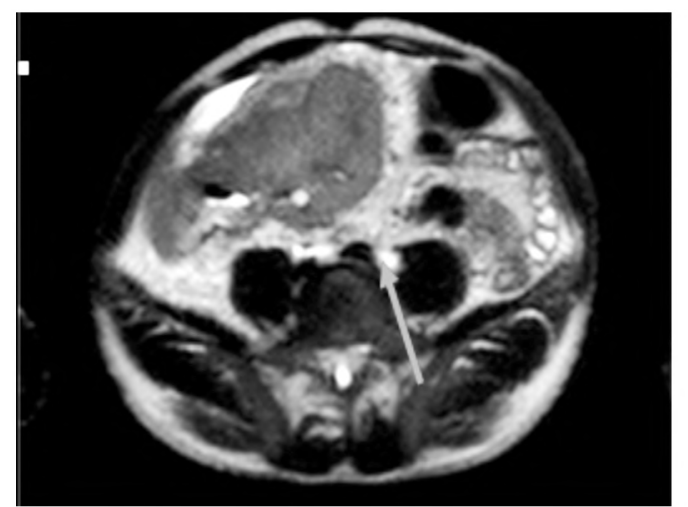

(A) Axial T2WI

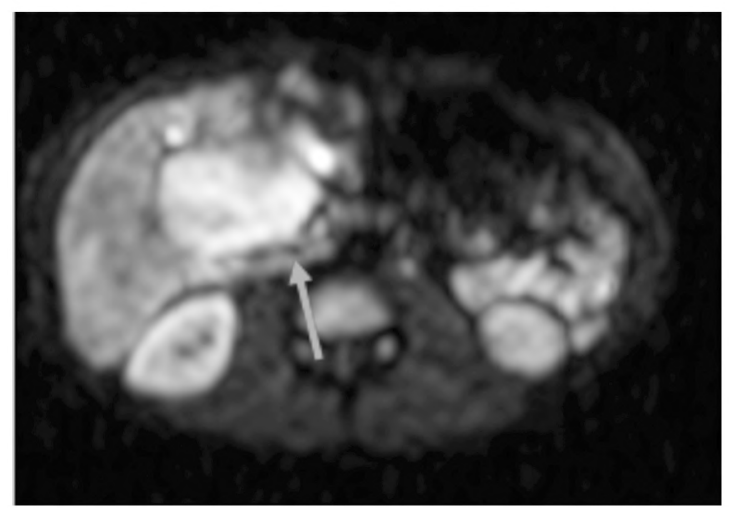

(C) Axial DWI at b 1000

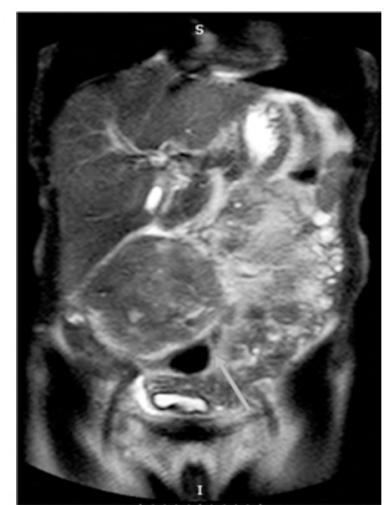

(B) Sagittal T2WI

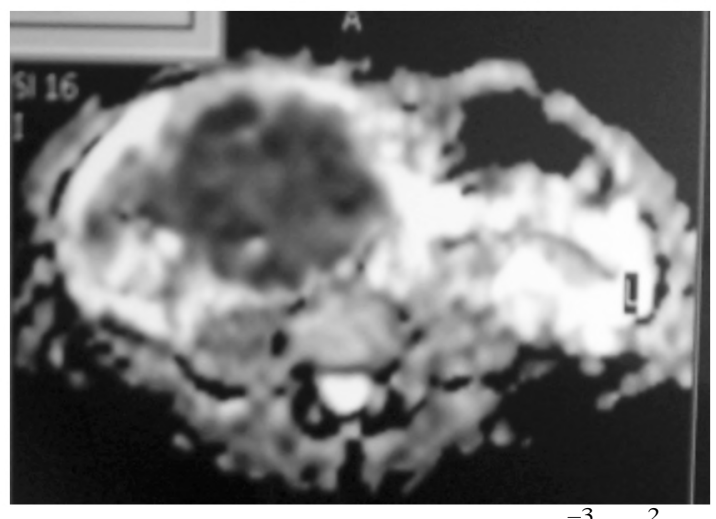

(D) ADC map and ADC value $\left(0.619 \times 10^{-3} \mathrm{~mm}^{2} / \mathrm{sec}\right)$

Fig. (5): Male patient, 50 years old, presented by Anaemia and right hypochondrial mass. (A,B) Images show hypoechoic mass measures $11 \times 13 \mathrm{~cm}$ affecting hepatic flexure and proximal transverse colon with infiltration of surrounding fat planes. (C,D) Images show restricted diffusion at the above-mentioned hepatic flexure mass with ADC value $=0.619 \times 10$ $\mathrm{mm}^{2} / \mathrm{sec}$. The histopathological diagnosis was poorly differentiated adenocarcinoma.

Table (4): Comparison between positive and negative histopathological diagnosis as regards ADC.

\begin{tabular}{llccc}
\hline & \multicolumn{2}{c}{ Histopathological diagnosis } & \multicolumn{2}{c}{$t$-test } \\
\cline { 3 - 5 } & Negative & Positive & $t$-test & $p$-value \\
\hline ADC, mean \pm SD & $1.93 \pm 0.41$ & $0.91 \pm 0.13$ & 7.23 & $<0.001 * *$ \\
\hline **: Statistically significant difference $(p$-value $<0.05)$. &
\end{tabular}

Table (5): Cut off value, sensitivity, specificity, PPV, NPV and accuracy of ADC to predict histopathological diagnosis.

\begin{tabular}{|c|c|c|c|c|c|c|}
\hline AUC & Cutoff & Sensitivity & Specificity & PPV & NPV & Accuracy \\
\hline ADC 0.912 & $\leq 1.1$ & 82.8 & $100.0 \%$ & $100.0 \%$ & 60.0 & 86.7 \\
\hline
\end{tabular}

PPV: Positive Predictive Value.

NPV: Negative Predictive Value.

\section{Discussion}

Rectal cancer is considered as one of the most common malignant tumors of the gastrointestinal tract. It is considered the third most common cancer in both men and women [6]. In addition it is considered to be one of the most common tumors in developed countries [7].
DW-MRI is a functional imaging technique that yields qualitative and quantitative information and provides unique insights regarding tumor cellularity, integrity of cell membranes, and microcirculation. The motion of water molecules is more restricted in tissues with a high cellular density that are associated with numerous intact cell membranes (e.g., tumor tissue). ADC, which are quantitative expressions of diffusion characteristics of tissues, tend to decrease in diffusion restricted areas, whereas diffusion Signal Intensity (SI), which is the qualitative parameter of diffusion, increases in those areas [8].

Our study included a total of 15 patients with suspected colorectal cancers either clinically, endoscopically or by CT and US images. In our study, all patients were subjected to clinical and laboratory assessment. For full evaluation of the pelvis we used axial and sagittal T2WI, Axial T2-STIR, Axial T 1 WI and DWI. Coronal T2WI was also done for evaluation of the whole abdomen. These sequences were also used by Sun YS \& colleagues [9].

In our study, we correlated the DWI findings and the ADC values with the histopathological 
results in predicting the malignant colorectal masses. A study done by Kaur et al., studied the correlation between established DWI with the histopathological findings [7].

In our study, the most common risk factor for CRC among the patients is family history of CRC by percent of (20\%); this is in agreement with the study done by Thoeny $\mathrm{HC}$ et al., [3]

In the present study, the most common location of colorectal mass among our patients is (the rectosigmoid region) with the liver presenting the most common site of CRC metastasis. This is reported by Mayer RJ [6]

Statistical significant difference was found between the mean ADC values of the benign and malignant colorectal masses in ADC maps which were compared by independent $t$-test. Same results were mentioned by Kim DJ \& colleagues [10]

In our study, significant change was found in signal intensity on DWI of colorectal masses-either benign or malignant-which is statistically significant. This is similar to the results reported by Song $\&$ Colleagues [11].

The results of current study showed that using histopathology for diagnosis of Colorectal Cancer regarding to comparison between positive and negative histopathological diagnosis versus ADC revealed a statistical significant difference at $p$ value $<0.01$. This result revealed the accuracy of ADC in diagnosis of colorectal cancer which is in agreement with study done by Marouf et al., as their study reported that correlation of ADC with histopathological results revealed an accurate diagnosis of the tumor. So this finding reflected that ADC values may indeed be a powerful prognostic indicator during the assessment and treatment of colorectal cancer [12]

ROC analysis of ADC values yielded an AUC of 0.912 , setting a threshold ADC value of $<1.1 \mathrm{X}$ $10^{-3} \mathrm{~mm} / \mathrm{sec}$ yielded a sensitivity of $82.8 \%$ and specificity of $100 \%$ in detecting the malignant colorectal masses.

Similar results reported by Kilickesmez $\mathrm{O}$ et al., 3 with cut-off value for carcinomas of $1.14 \mathrm{X}$ $10^{-3} \mathrm{~mm} / \mathrm{s}$ yielded a sensitivity and specificity of $93.3 \%$ and $93.3 \%$, respectively [13].

A study reported by Afifi \& colleagues showed that addition of DWI to the conventional MR images lead to increased sensitivity and specificity compared to the use of conventional MRI (T2WI only) $96.1 \%$ and $100 \%$ respectively. PPV was
$100 \%$, NPV was $80 \%$ and accuracy for detection was $96.6 \%$ [14]. In addition to similarity results were reported by Haider et al., and Kumar et al., as both of studies revealed the improvement of imaging when combined with DWI due to improving of sensitivity level from $54 \%$ to $81 \%$ [15,16].

\section{Conclusion:}

DWI with high b-values and ADC value is a feasible method and has the potential to be effective in detection of colorectal cancer.

Conflicts of interest:

There are no conflicts of interest.

\section{References}

1- BOLAND C.R., YAMAD T., ALPERS D., KAPLOWITZ N., et al.: Malignant tumors of the colon, Textbook of gastroenterology. 4 th edition. Philadelophia: Lippincott Williams and Wilkins, p. 1940-90, 2003.

2- DZIK-JURASZ A., DOMENIG C., GEORGE M., et al.: Diffusion MRI for prediction of response of rectal cancer to chemoradiation. Lancet, 360: 307-8, 2002.

3- THOENY H.C., De KEYZER F., CHEN F., et al.: Diffusion weighted MR imaging in monitoring the effect of a vascular targeting agent on rhabdomyosarcoma in rats. Radiology, 234: 756-64, 2005.

4- ROTH Y., TICHLER T., KOSTENICH G., et al.: Highb-value diffusion-weighted MR imaging for pretreatment prediction and early monitoring of tumor response to therapy in mice. Radiology, 232: 685-92, 2004.

5- PADHANI A.R., LIU G., KOH D.M., et al.: Diffusion weighted magnetic resonance imaging as a cancer biomarker: Consensus and recommendations. Neoplasia, 11: 102-25, 2009

6- MAYER R.J.: Gastrointestinal tract cancer. In: Longo D.L., Fauci A.S., Kasper D.L., et al., eds. Harrison's Principles of Internal Medicine. $18 \mathrm{t}^{\mathrm{h}}$ ed. New York, NY: McGraw Hill Medical, 2012.

7- KAUR H., CHOI H., YOU N., et al.: MR imaging for preoperative evaluation of primary rectal cancer: Practical considerations. Radio Graphics, 32: 389-409, 2012.

8- KOH D.M. and COLLINS D.J.: Diffusion-weighted MRI in the body: Applications and challenges in oncology. A.J.R. Am. J. Roentgenol., 188: 1622-35, 2007.

9- SUN Y.S., ZHANG X.P., TANG L., et al.: Locally advanced rectal carcinoma treated with preoperative chemotherapy and radiation therapy: Preliminary analysis of diffusion weighted MR imaging for early detection of tumor histopathologic down staging. Radiology, 254: 170-8, 2010.

10- KIM D.J., KIM J.H., LIM J.S., et al.: Restaging of rectal cancer with MR imaging after concurrent chemo therapy and radiation therapy. Radiographics, 30: 503-16, 2010.

11- SONG I., KIM S.H., LEE S.J., CHOI J.Y., KIM M.J. and RHIM H.: Value of diffusion-weighted imaging in the detection of viable tumour after neoadjuvant chemo radiation therapy in patients with locally advanced rectal 
cancer: Comparison with T2-weighted and PET/CT imaging. Br. J. Radiol., 85: 577-86, 2012.

12- MAROUF R.A., TADROS M.Y. and AHMED T.Y.: Value of diffusion-weighted MR imaging in assessing response of neoadjuvant chemo and radiation therapy in locally advanced rectal cancer. The Egyptian Journal of Radiology and Nuclear Medicine, 46: 553-61, 2015.

13- KILICKESMEZ O., ATILLA S., SOYLU A., et al.: Diffusion-weighted imaging of the rectosigmoid colon Preliminary findings. J. Comput. Assist. Tomogr., 33: 863-6, 2009.

14- AFIFI A.H.A.A., ETABY A.N., AHMAD M.A.Y. and FARGHALYA Y.T.: Value of diffusion weighted magnetic resonance imaging in the prediction of cancer prostate Alexandria Journal of Medicine, 49: 57-66, 2013.

15- HAIDER M.A., VAN DER KWAST T.H., TANGUAY J., EVANS A.J., HASHMI G., LOCKWOOD G., et al.: Combined T2-weighted and diffusion weighted MRI for localization of prostate cancer. Am. J. Roentgenol., 189 (2): 323, 2007.

16- KUMAR V., JAGANNATHAN N.R., KUMAR R., THULKAR S., GUPTA S.D., DWIVEDI S.N., et al.: Apparent diffusion coefficient of the prostate in men prior to biopsy: Determination of a cut off value to predict malignancy of the peripheral zone. NMRBiomed, 20 (5): 505-11, 2007.

\title{
دور الرنين المغناطيسى فى خاصية الإنتشار فى سرطان القولون والمستقيم
}

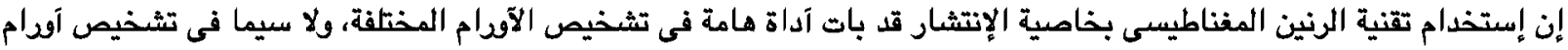

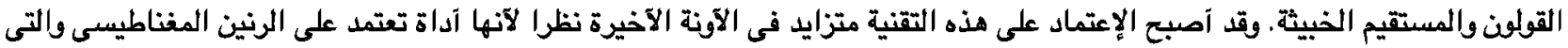 \\ لا تخترق الآنسجة مقارنة بآخذ عينات من الآنسجة لتحليلها باثلولوينيا. \\ وتعتمد هذه التقنية على قياس خصائص الآنسجة البيولوجية نتيجة إنتشار الماء من نسيج إلى آخر. كما آنها تستطيع التمييز بين الآنسجة \\ الحميدة والآخرى الخبيثة نتيجة لإختلاف خصائص إنتشار الماء طبقا لإختلافت تركيب النسيج الناتج عن الورم. \\ الهدف من الدراسة: في هذه الدراسة نحاول تقييم دور الرنين المغناطيسى بإستخدام خاصية الإنتشار في تشخيص آودام القولون \\ والمستقيم الخبيثة، وإمكانية التفرقة بينها ويين الآورام الحميدة. \\ وقد إشتملت هذه الدراسة على 10 مريض وقد تم عمل رنين مغناطيسى وتصوير بإستخدام خاصية الإنتشار ولقد تم تحليل الييانات وقد \\ قورنت النتائج بالتحليل الباثولوجى للآنسجة. \\ وقد وجد إرتباط قوى بين معامل الإنتشار الظاهر لخاصية الإنتشار ونتائج تحليل الآنسجة باثولوجيا فى قياس شدة إلتهاب البنكرياس. \\ من دراستنا نستتج آن التصوير بالرنين المغناطيسى وخاصية الإنتشار بإمكانه تشخيص حالات آودام القولون والمستقيم الخييثة وتفرقتها \\ من الآورام الحميدة.
}

